\title{
Frequency and Distribution of $r p h 2$ Gene in Tribolium castaneum Collected from Grain Supply Chain of Coimbatore, Kangeyam and Theni
}

\author{
C. Taraka and S. Mohankumar* \\ Department of Plant Biotechnology, Tamil Nadu Agricultural University, \\ Coimbatore-641003, India \\ *Corresponding author
}

\section{A B S T R A C T}

\section{Keywords}

Tribolium

castaneum,

Phosphine

resistance, $r p h 2$ gene, CAPS marker

Article Info

Accepted:

17 October 2019

Available Online:

10 November 2019
Resistance to insecticides is a worldwide issue for the major stored insect pests. Among several insecticides, phosphine $\left(\mathrm{PH}_{3}\right)$ gas is the most commonly used fumigant to protect the stored product from pests. Conventionally, a discriminating-dose bioassay is conducted to determine the phosphine resistance in stored insect pests. In the present study, the frequency of resistance is estimated in Tribolium castaneum (Herbst) populations collected from grain supply chain viz., (Grain processing unit, bulk grain storage godowns, ration shop, wholesale shop, retail shop and household) from three locations of Tamil Nadu, India. Based on a cleaved amplified polymorphic sequence (CAPS) method, each individual insect is analysed using restriction enzyme to detect strong resistance allele. Among the populations collected from grain supply chain of Theni, Coimbatore and Kangeyam, the samples (T. castaneum) from bulk grain storage showed the highest frequency of phosphine resistant allele of viz., 85.71, $78.33,89.13 \%$, respectively while as the lowest frequency of phosphine resistant allele was observed in household samples of Theni, Coimbatore and Kangeyam viz.,18.75, $34.48,40.74 \%$, respectively. Thus, strong phosphine resistance detected in beetle with the help of CAPS marker could be used for the improvement of management strategies for the given pest populations.

\section{Introduction}

India is the second largest producer of food grains and also a major exporter of cereals globally. Around 50 per cent of produce is stored by the farmers for their consumption and remaining surplus grains are procured by the government based stored grain agency like Food Corporation of India (FCI) and state warehouses. However, the wastage of food grains is witnessed due to lack of storage infrastructure and primitive grain handling mechanism. It is reported that post harvest grain losses in India is upto 12 to 16 million metric tons of food grains each year. The major loss is due to stored product insect pests which plays a key role in food grain deterioration and wastage is upto $5-10 \%$. 
Because of stored grain insect pest infestation the grains nutrients are degraded and makes it tasteless and valueless (Jood and Kapoor, 1996). Globally, several insect pests have been reported. Among them, Tribolium castaneum (Herbst) (Coleoptera; Tenebrionidae) is one of the most important secondary insect pests though it feeds on flour and other milled products (Good, 1936).

Phosphine $\left(\mathrm{PH}_{3}\right)$ gas fumigation is by far the most commonly used method for the management of insect pests in stored grains. This fumigant is efficient to use as it is toxic to all stored insects pests and their life stages (Chaudhry, 1997).

Ease of application, no residue, less cost and effectiveness are the advantages of phosphine (Nath et al., 2011). Continuous application and exposure of phosphine has led to the development of strong resistance in stored insect pests which includes Rhyzopertha dominica (F.), Tribolium castaneum (Herbst) and Cryptolestes ferrugineus (Collins et al., 2002; Benhalima et al., 2004; Lorini et al., 2007; Opit et al., 2012; Nayak et al., 2013). Resistance level has been categorized into two factors (i.e.) strong and weak resistance (Collins, 1998; White and Lambkin, 1990).

Phosphine resistance in Tribolium castaneum is identified and it is coded by two major autosomal genes rph1 and rph2 which combined together to produce strong resistance. Rphl is responsible for weak resistance, while rph2 provides strong resistance (Schlipalius et al., 2002; Jagadeesan et al., 2012). Schlipalius et al., (2012) reported that a mutation was found in Dihydrolipomide dehydrogenase (dld) gene at the rph2 locus in the $R$. dominica and $T$. castaneum which lead to the development of resistance against phosphine. Variation in amino acid sequence in amplified 368bp fragment of dld gene and to confer resistance, a cleaved amplified polymorphic sequence (CAPS) analysis was performed using the MboI restriction enzyme which cleaves the $d l d$ gene into two fragments 296bp and 72bp in lengths (Schlipalius et al., 2012; Kaur et al., 2015). Schlipalius et al., (2018) developed an assay for detecting strong phosphine resistance allele genes in dld gene of $R$. dominica using next-generation sequencing.

The distribution and frequency of resistance variants were estimated in thousands of individual insects in single run. In 1435 individuals collected from grain storage sites including farms and central storage across eastern Australia, resistance alleles were detected in $49 \%$ samples (38\% farms, $60 \%$ of central storages). Two resistance variants (P49S and K142E) were widely found among other resistance alleles.

The present study investigated the frequency and distribution of phosphine resistance in $T$. castaneum collected from grain supply chain (Processing unit, bulk grain storage godowns, ration shop, wholesale shop, retail shop and households) of Coimbatore, Tiruppur (Kangeyam) and Theni districts. The rph2 resistance allele frequency was measured by genotyping the insect population using cleaved amplified polymorphic sequence (CAPS) analysis. Based on this the resistance frequency was compared among three districts of Tamil Nadu.

\section{Materials and Methods}

\section{Insect culture and survey}

T. castaneum insect samples were collected from grain supply chain (Processing unit, bulk grain storage godowns, ration shop, wholesale shop, retail shop and households) of three different districts [Coimbatore, Tiruppur (Kangeyam) and Theni] of Tamil Nadu. These samples were cultured in whole wheat flour 
and maintained at $30{ }^{\circ} \mathrm{C}$ and $55 \%$ relative humidity.

\section{Bioassay for phenotype characterization and Statistical Analysis}

T. castaneum adult insects were fumigated with two discriminating concentration of phosphine gas, low concentration (0.03 $\mathrm{mg} \mathrm{L}^{-1}$ ) (White and Lambkin, 1990) and high concentration $\left(0.25 \mathrm{mg} \mathrm{L}^{-1}\right)$ (Daglish and Collins, 1999).To detect weak and strong phosphine resistance the insects were exposed for about 20hrs. Fumigation was performed at a relative humidity of $30 \pm 2^{\circ} \mathrm{C}$ and $60 \pm 5$ percent. Each test was replicated three times in which 50 insects/replication were maintained in Control and Test.

After exposure, insects were transferred on wheat flour to feed on and maintained in the culture room. Mortality was calculated after seven days from the end of the exposure time as reported by FAO. Statistical data analysis (RBD) was carried out using WASP 2.0 software for the bioassay replications (R1 to $\mathrm{R} 4$, respectively) and the overall SEd and CV values were also obtained (Table 1-3).

\section{Genomic DNA extraction}

Genomic DNA was extracted from $T$. castaneum samples using CTAB method (Doyle and Doyle 1987). The DNA extraction buffer contained $100 \mathrm{mM}$ Tris. $\mathrm{HCl}(\mathrm{pH} \mathrm{8}), 10$ mM EDTA, $1.4 \mathrm{M} \mathrm{NaCl}, 2 \%$ CTAB and 5\% $\beta$-mercaptoethanol. Individual insect samples were homogenized with $200 \mu \mathrm{l}$ of DNA extraction buffer and incubated at $65^{\circ} \mathrm{C}$ for 1 $\mathrm{h}$. The tubes were removed from the water bath and allowed to cool at room temperature. Chloroform: isoamyl alcohol mixture (24:1, v/v) (0.8 volumes) was added and mixed by inversion for $10 \mathrm{~min}$. to form an emulsion. It was centrifuged at $12,000 \mathrm{rpm}$ for $10 \mathrm{~min}$. and the clear aqueous phase was transferred to a new sterile tube. Ice-cold iso-propanol (0.7 volumes) was added and mixed gently by inversion and it was stored at $-20^{\circ} \mathrm{C}$ for overnight. It was then centrifuged at 12,000 rpm for 10 minutes to pellet the DNA and the supernatant was discarded. The DNA pellet was washed with $70 \%$ ethanol. After washing, DNA pellet was air dried and dissolved in 20$40 \mu 1$ of TE buffer depending on size of the pellet and stored at $-20^{\circ} \mathrm{C}$ until use. The isolated DNA was checked for its quality by separating in $0.8 \%$ agarose gel electrophoresis and quantified by spectrophotometer.

\section{Amplification and Genotyping}

A single nucleotide polymorphism (SNP) present in the gene sequences of the $d l d$ is identified using a cleaved amplified polymorphic sequence (CAPS) marker assay in the insects collected. In T. castaneum, the dld gene fragment is amplified using PCR in a reaction volume of $25 \mu \mathrm{l}$ containing $2.5 \mu \mathrm{l}$ of $10 \times$ PCR buffer, $1 \mu \mathrm{l}$ of $10 \mu \mathrm{M}$ forward $\left(5^{\prime}-\right.$ GCCCTGACTGTCTTCCACCA-3') and reverse (5'-AGCCTTGACAGCATTTTCCT$\left.3^{\prime}\right)$ primer, $0.5 \mu \mathrm{l}(1.5 \mathrm{U})$ of Taq polymerase and $2 \mu \mathrm{l}(50 \mathrm{ng})$ of template DNA. The PCR conditions consisted of $5 \mathrm{~min}$ at $95^{\circ} \mathrm{C}$, followed by 35 cycles of $95{ }^{\circ} \mathrm{C}$ for $1 \mathrm{~min}, 55$ ${ }^{\circ} \mathrm{C}$ for $30 \mathrm{~s}$ and $72{ }^{\circ} \mathrm{C}$ for $1 \mathrm{~min}$ and a final extension at $72{ }^{\circ} \mathrm{C}$ for $7 \mathrm{~min}$. Amplified products were screened using agarose gel electrophoresis (1.5\%). The amplified 368-bp product was digested with $1 \mathrm{U}$ of $\mathrm{MboI}$ at 37 ${ }^{\circ} \mathrm{C}$ for $4 \mathrm{~h}$ in a reaction volume of $15 \mu \mathrm{l}$ containing $5 \mu \mathrm{l}$ of PCR product, $1 \mu \mathrm{l}$ of $10 \times$ buffer, $0.5 \mu \mathrm{l}$ of $\mathrm{MboI}$ enzyme and $8.5 \mu \mathrm{l}$ of nuclease-free water. The digested product was visualized using $3 \%$ agarose gel electrophoresis. Thus, presence of the resistant variant results in cleavage of the PCR product into $296 \mathrm{bp}$ and $72 \mathrm{bp}$ fragments.

\section{Results and Discussion}

Grains are stored and distributed to the market 
through grain supply chain. These stored grains are affected by both biotic and abiotic factors. Comparatively, a biotic factor such as insects, mites, rodents, fungi etc., causes severe damage to the grains. Fumigation method is used for controlling these insect pests throughout the storage period. $80 \%$ of the insect pests are controlled by phosphine gas which is the only reliable fumigant (Chaudhry, 2000). Among these insect pests, resistance to phosphine is increasing day-byday due to several factors like improper handling and frequent use of phosphine fumigant (Rafter et al., 2017). Especially, high level of phosphine resistance is reported in $T$. castaneum (Rajendran, 1998). However, the comprehensive molecular study of development of resistance against pesticide imparts the data towards the development of resistance management strategy. It was reported that strong resistance to phosphine in stored grain insect pests was mainly regulated by two major genes (Ansell, 1992, Schlipalius et al., 2002). Weak-R phenotype in stored insect pests is controlled by single major gene, rphl. In addition, the strong- $\mathrm{R}$ phenotype is developed by the combination of rphl and a second factor, rph2 (Collins et al., 2002; Schlipalius et al., 2008). The present study was carried out to determine the frequency and distribution of phosphine resistance allele in key stored insect pests viz., Tribolium castaneum at molecular level using rph2 gene, which was related to strong phosphine resistance in storage pests. From grain supply chain, only few reports are available on frequency and distribution of phosphine resistance allele at rph2 in key stored insect pests.

In this study, total of 473 individuals of $T$. castaneum were examined for the frequency and distribution of phosphine resistance allele (RR) at rph2 in grain supply chain of Coimbatore, Tiruppur (Kangayam) and Theni districts of Tamil Nadu, India. The phosphine resistance allele (RR) frequency varied from 85.71 to 18.75 per cent in Coimbatore, whereas it was 78.33 to 34.48 per cent in Kangayam and 89.13 to 24.07 per cent in Theni across grain supply chain.

Among the population collected from Coimbatore grain supply chain, the highest frequency of phosphine resistance allele were recorded in bulk grain storage $(85.71 \%$ for FCI) and Ration shop (63.46\%). The moderate frequency of phosphine resistance allele $(48.33 \%)$ was observed in the wholesale shop. Retail shop and household samples recorded low frequency of phosphine resistance allele (37.50 and $18.75 \%$, respectively) and high frequency of susceptible allele (81.25 and $62.05 \%$, respectively).

Individuals having atleast one "R" allele was calculated for all the individuals from grain supply chain. Samples collected from ration shop and bulk grain storage showed 96.15 and $89.28 \%$ having one " $\mathrm{R}$ " allele. Wholesale shop and retail shop samples were recorded with 80 and $71.42 \%$ having atleast one "R" allele. However, the lowest number of individuals having at least one "R" allele was observed in household samples (37.5 \%) (Table 4).

Similarly, Kangayam population collected from grain supply chain were analysed for frequency of phosphine resistance allele. Among them the highest frequency of phosphine resistance allele were recorded in bulk grain storage (78.33\% for TNCSC) (Plate $1 \& 2$ ), processing unit and ration shop (62.96 and $60 \%)$ respectively.

The moderate frequency of phosphine resistance allele (55.76 and $53.70 \%$, respectively) was observed in wholesale shop and retail shop. The samples collected from household were recorded with low frequency of phosphine resistance allele $(34.48 \%)$ and 
high frequency of susceptible allele (65.51\%). recorded 96.66 and $92.30 \%$ of individuals Bulk grain storage and wholesale shop were having at least one "R" allele.

\begin{tabular}{|c|c|c|c|}
\hline \multicolumn{3}{|c|}{ Table.1 Bioassay and statistical data analysis of T. castaneum populations collected from } \\
Coimbatore region
\end{tabular}

\begin{tabular}{|c|c|c|c|}
\hline \multirow[b]{2}{*}{ Sr.No } & \multirow[b]{2}{*}{ Location } & \multicolumn{2}{|c|}{ Percent Resistance $($ Mean \pm SE) } \\
\hline & & Low conc. $(0.03 \mathrm{mg} / \mathrm{L})$ & High conc. $(0.25 \mathrm{mg} / \mathrm{L})$ \\
\hline 1 & Storage Godown (TNCSC) & $\begin{array}{c}86.52 \pm 2.94 \\
(68.47)^{\mathrm{a}}\end{array}$ & $\begin{array}{c}67.42 \pm 3.85 \\
(55.58)^{\mathrm{a}}\end{array}$ \\
\hline 2 & Rice Mill & $\begin{array}{c}85.39 \pm 2.22 \\
(67.55)^{\mathrm{a}}\end{array}$ & $\begin{array}{c}51.69 \pm 4.84 \\
(46.19)^{\mathrm{b}}\end{array}$ \\
\hline 3 & Ration Shop & $\begin{array}{c}82.02 \pm 2.94 \\
(64.94)^{\mathrm{b}}\end{array}$ & $\begin{array}{c}47.19 \pm 3.85 \\
(43.38)^{c}\end{array}$ \\
\hline 4 & Whole Sale shop & $\begin{array}{c}75.28 \pm 2.94 \\
(60.19)^{c}\end{array}$ & $\begin{array}{c}42.70 \pm 2.22 \\
(41.03)^{\mathrm{d}}\end{array}$ \\
\hline 5 & Retail Shop & $\begin{array}{c}67.42 \pm 3.85 \\
(55.20)^{\mathrm{d}}\end{array}$ & $\begin{array}{c}33.71 \pm 3.85 \\
(35.74)^{\mathrm{e}}\end{array}$ \\
\hline 6 & House Hold & $\begin{array}{c}59.55 \pm 2.94 \\
(50.50)^{\mathrm{e}}\end{array}$ & $\begin{array}{c}17.98 \pm 2.94 \\
(25.44)^{\mathrm{f}}\end{array}$ \\
\hline & Sed & 0.24 & 0.14 \\
\hline & $\mathrm{CV} \%$ & 1.91 & 1.61 \\
\hline
\end{tabular}




\begin{tabular}{|c|c|c|c|}
\hline \multicolumn{4}{|c|}{$\begin{array}{l}\text { Table.3 Bioassay and statistical data analysis of } T \text {. castaneum populations collected } \\
\text { from Theni region }\end{array}$} \\
\hline \multirow[t]{2}{*}{ S.No } & \multirow[t]{2}{*}{ Location } & \multicolumn{2}{|c|}{ Percent Resistance $($ Mean \pm SE $)$} \\
\hline & & Low conc. $(0.03 \mathrm{mg} / \mathrm{L})$ & High conc. $(0.25 \mathrm{mg} / \mathrm{L})$ \\
\hline 1 & Storage Godown (CWC) & $\begin{array}{c}98.89 \pm 1.11 \\
(84.25)^{\mathrm{a}}\end{array}$ & $\begin{array}{c}85.56 \pm 2.94 \\
(67.69)^{\mathrm{a}}\end{array}$ \\
\hline 2 & Rice Mill & $\begin{array}{l}87.36 \pm 2.22 \\
(69.21)^{\mathrm{b}}\end{array}$ & $\begin{array}{l}68.97 \pm 3.85 \\
(56.55)^{\mathrm{b}}\end{array}$ \\
\hline 3 & Ration Shop & $\begin{array}{l}80.90 \pm 3.85 \\
(64.49)^{\mathrm{c}}\end{array}$ & $\begin{array}{l}59.55 \pm 4.01 \\
(50.86)^{\mathrm{c}}\end{array}$ \\
\hline 4 & Whole Sale shop & $\begin{array}{l}78.89 \pm 2.94 \\
(63.02)^{\mathrm{c}}\end{array}$ & $\begin{array}{l}57.78 \pm 5.88 \\
(49.47)^{\mathrm{c}}\end{array}$ \\
\hline 5 & Retail Shop & $\begin{array}{c}78.16 \pm 2.94 \\
(62.39)^{\mathrm{c}}\end{array}$ & $\begin{array}{c}51.72 \pm 5.09 \\
(46.55)^{\mathrm{d}}\end{array}$ \\
\hline 6 & House Hold & $\begin{array}{c}68.97 \pm 3.85 \\
(56.51)^{\mathrm{d}}\end{array}$ & $\begin{array}{c}45.98 \pm 2.94 \\
(43.02)^{\mathrm{e}}\end{array}$ \\
\hline & Sed & 0.37 & 0.20 \\
\hline & $\mathrm{CV} \%$ & 2.74 & 1.90 \\
\hline
\end{tabular}

\begin{tabular}{|c|c|c|c|c|c|c|c|c|}
\hline $\begin{array}{c}\text { S. } \\
\text { No }\end{array}$ & Location & $\begin{array}{c}\text { Total } \\
\text { number } \\
\text { of } \\
\text { samples }\end{array}$ & (RR) & (RS) & (SS) & $\begin{array}{c}\text { 'R' } \\
\text { Alleles } \\
(\%)\end{array}$ & $\begin{array}{c}\text { 'S' } \\
\text { Alleles } \\
(\%)\end{array}$ & $\begin{array}{c}\text { Percentage of } \\
\text { individuals } \\
\text { having at } \\
\text { least one } \\
\text { "R" allele }\end{array}$ \\
\hline 1. & $\begin{array}{l}\text { Bulk grain } \\
\text { storage } \\
\text { FCI }\end{array}$ & 28 & 23 & 2 & 3 & 85.71 & 14.28 & 89.28 \\
\hline 2. & $\begin{array}{c}\text { Public } \\
\text { Distribution } \\
\text { Shop (Ration } \\
\text { shop) }\end{array}$ & 26 & 8 & 17 & 1 & 63.46 & 36.53 & 96.15 \\
\hline 3. & Wholesale shop & 30 & 5 & 19 & 6 & 48.33 & 51.66 & 80.00 \\
\hline 4. & Retail shop & 28 & 1 & 19 & 8 & 37.50 & 62.5 & 71.42 \\
\hline 5. & House hold & 24 & 0 & 9 & 15 & 18.75 & 81.25 & 37.50 \\
\hline
\end{tabular}




\begin{tabular}{|c|c|c|c|c|c|c|c|c|}
\hline $\begin{array}{l}\text { S. } \\
\text { No }\end{array}$ & Location & $\begin{array}{c}\text { Total } \\
\text { number } \\
\text { of } \\
\text { samples }\end{array}$ & (RR) & (RS) & (SS) & $\begin{array}{c}\text { 'R' } \\
\text { Alleles } \\
(\%)\end{array}$ & $\begin{array}{c}\text { 'S' } \\
\text { Alleles } \\
(\%)\end{array}$ & $\begin{array}{l}\text { Percentage of } \\
\text { individuals } \\
\text { having at least } \\
\text { one " } R \text { " allele }\end{array}$ \\
\hline 1. & $\begin{array}{l}\text { Bulk grain storage } \\
\text { TNCSC }\end{array}$ & 30 & 18 & 11 & 1 & 78.33 & 21.66 & 96.66 \\
\hline 2. & $\begin{array}{l}\text { Grain processing } \\
\text { unit (Rice mill) }\end{array}$ & 27 & 10 & 14 & 7 & 62.96 & 51.85 & 88.88 \\
\hline 3. & $\begin{array}{l}\text { Public Distribution } \\
\text { Shop (Ration shop) }\end{array}$ & 30 & 12 & 12 & 6 & 60.00 & 40.00 & 80.00 \\
\hline 4. & Wholesale shop & 26 & 6 & 17 & 2 & 55.76 & 44.23 & 92.30 \\
\hline 5. & Retail shop & 27 & 5 & 19 & 2 & 53.70 & 42.59 & 88.88 \\
\hline 6. & House hold & 29 & 1 & 18 & 10 & 34.48 & 65.51 & 65.51 \\
\hline
\end{tabular}

\begin{tabular}{|c|c|c|c|c|c|c|c|c|}
\hline $\begin{array}{l}\text { S. } \\
\text { No }\end{array}$ & Location & $\begin{array}{c}\text { Total } \\
\text { number of } \\
\text { samples }\end{array}$ & (RR) & (RS) & (SS) & $\begin{array}{l}\text { 'R' } \\
\text { Alleles } \\
(\%)\end{array}$ & $\begin{array}{l}\text { 'S' } \\
\text { Alleles } \\
(\%)\end{array}$ & $\begin{array}{c}\text { Percentage of } \\
\text { individuals having } \\
\text { at least one " } R \text { " allele }\end{array}$ \\
\hline 1. & $\begin{array}{l}\text { Bulk grain storage } \\
\text { CWC }\end{array}$ & 23 & 20 & 1 & 2 & 89.13 & 10.86 & 91.30 \\
\hline 2. & $\begin{array}{l}\text { Grain processing } \\
\text { unit (Rice mill) }\end{array}$ & 30 & 16 & 13 & 1 & 75.00 & 25.00 & 96.66 \\
\hline 3. & $\begin{array}{c}\text { Public } \\
\text { Distribution Shop } \\
\text { (Ration shop) }\end{array}$ & 29 & 15 & 13 & 1 & 74.13 & 25.86 & 96.55 \\
\hline 4. & Wholesale shop & 30 & 15 & 14 & 1 & 73.34 & 26.66 & 96.67 \\
\hline 5. & Retail shop & 29 & 1 & 13 & 15 & 25.86 & 74.13 & 48.28 \\
\hline 6. & House hold & 27 & 2 & 9 & 16 & 24.07 & 75.92 & 40.74 \\
\hline
\end{tabular}

Plate.1 Amplification of rph2 gene in individual samples of Tribolium castaneum Kangeyam (TNCSC) population

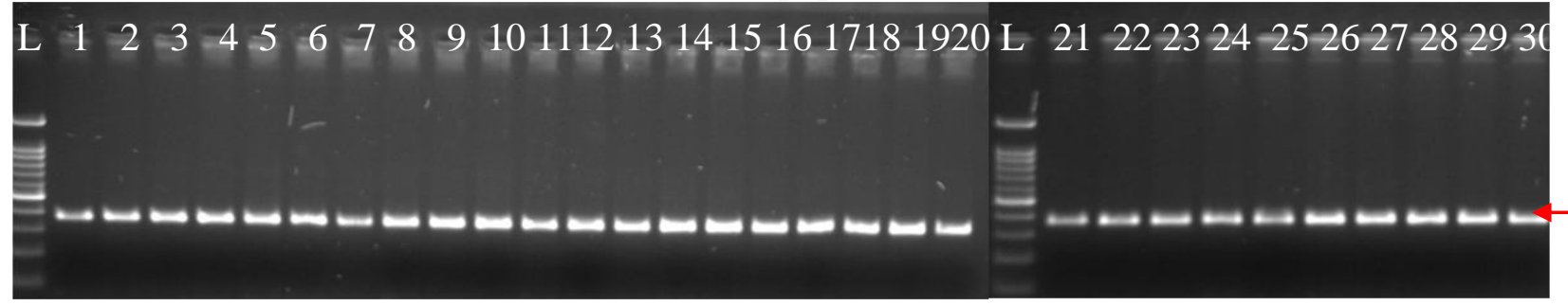


Plate.2 PCR - RFLP analyses of individual sample of Tribolium castaneum Kangeyam (TNCSC) population
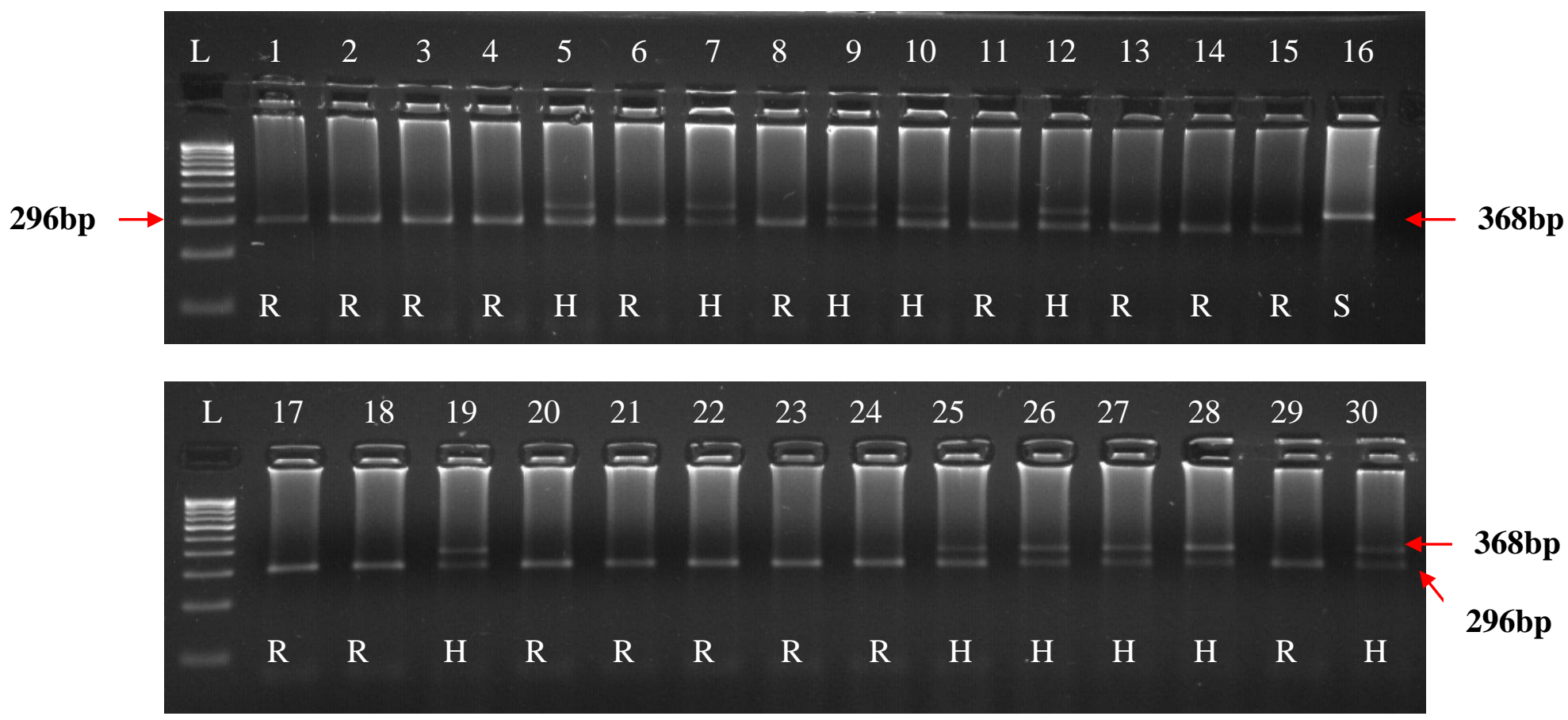

Lane L:100bp ladder ; R- Resistance ; H- Heterozygote ; S- Susceptible

Around $88.88 \%$ of individuals having at least one " $R$ " allele were observed in the samples collected from grain processing unit and retail shop and samples collected from ration shop were observed with $80 \%$ individuals having one " $\mathrm{R}$ " allele were $80 \%$. The lowest number of individuals having at least one " $\mathrm{R}$ " allele was observed in household samples $(65.51 \%)$ (Table 5).

Also, the frequency of phosphine resistance allele were evaluated in Theni grain supply chain in which the bulk grain storage showed the highest frequency of phosphine resistance allele (i.e) 89.13 per cent. Grain processing unit and ration shop and wholesale shop were recorded with moderate frequency of phosphine resistance allele of $(75,74.13$, $73.34 \%$, respectively). Relatively, the lowest frequency of phosphine resistance allele was recorded in retail shop and household samples (25.86 and $24.07 \%$, respectively) and the high level of frequency susceptible allele (74.13 and $75.92 \%$, respectively). Bulk grain storage, grain processing unit, ration shop and wholesale shop were observed with (91.30, 96.66, 96.55, 96.67\%, respectively) of individuals having at least one " $\mathrm{R}$ " allele. The lowest number of individuals having at least one " $R$ " allele were recorded in retail shop and household samples (48.28 and 40.74\%, respectively) (Table 6).

The present results indicated the presence of specific P45S allele of rph2 which is responsible for the strong resistance and also it was previously reported in other regions of the world (Schlipalius et al., 2012; Kaur et al., 2015; Chen et al., 2015; Kocak et al., 2015) the bulk grain storage population of $T$. castaneum of these three locations showed high level of frequency. Though the bulk grain storage indicated high frequency of $\mathrm{P} 45 \mathrm{~S}$ resistance allele it was suggested that this allele may be the most widespread allele worldwide, although it is likely to occur independently in all the multiple regions. This also suggests that the P45S allele confer the 
strongest phosphine resistance phenotype, and confers the least fitness cost. This would allow survival under selection pressures and maintenance in insect populations that breed outside of storages and are not exposed to phosphine. The pleiotropic enhancement of fitness has been observed in resistant $T$. castaneum individuals are extremely tolerant to starvation. In future, resistance markers combined with population genetic studies to assess patterns of gene flow, rates and patterns of selection for resistance will be able to be estimated, allowing us to enhance phosphine resistance management strategies.

\section{References}

Ansell, M. R. (1992). The mode of inheritance of resistance to phosphine in two species of stored product beetles, (PhD) Thesis. University of Reading, UK.

Benhalima, H., Chaudhry, M., Mills, K., and Price, N. (2004). Phosphine resistance in stored product insects collected from various grain storage facilities in Morocco. Journal of Stored Products Research, 40(3), 241-249.

Chaudhry, M (1997). A Review of the Mechanisms Involved in the Action of Phosphine as an Insecticide and Phosphine Resistance in Stored-Product Insects. Pest Management Science, 49(3), 213-228.

Chaudhry, M. (2000). Phosphine resistance. Pesticide Outlook, 11(3), 88-91.

Chen, Z., Schlipalius, D., Opit, G., Subramanyam, B., and Phillips, T. W. (2015). Diagnostic molecular markers for phosphine resistance in US populations of Tribolium castaneum and Rhyzopertha dominica. PloS one, 10(3), $\mathrm{e} 0121343$.

Collins, P. J., Daglish, G. J., Bengston, M., Lambkin, T. M., and Pavic, H. (2002). Genetics of resistance to phosphine in Rhyzopertha dominica (Coleoptera: Bostrichidae). Journal of economic entomology, 95(4), 862-869.
Collins, P.J. 1998. Resistance to grain protectants and fumigants in insect pests of stored products in Australia. In: Banks, H.J., E.J. Wright and K.A. Damcevski (eds.,). Stored grain in Australia. Proceddings of the Australian Post-harvest Technical Conference. CSIRO: Canberra. Australia, pp. 55 57.

Daglish, G.J. and P.J. Collins. 1999. Improving the relevance of assays for phosphine resistance. In: Proceedings of 7th International Working Conference on Stored- Product Protection, Beijing, China. Sichuan Publishing House of Science and Technology, Chengdu, China. 1998. pp. 584-593.

Doyle, J. J and Doyle, J.L (1987). A rapid DNA isolation procedure for small quantities of fresh leaf tissue. Phytochem Bull Bot Soc Am, 19, 11-15.

Good, N.E. 1936. The flour beetles of the genus Tribolium. USDA Technical Bulletin, 5: 27-28.

Jagadeesan, R., Collins, P. J., Daglish, G. J., Ebert, P. R., and Schlipalius, D. I. (2012). Phosphine resistance in the rust red flour beetle, Tribolium castaneum (Coleoptera: Tenebrionidae): inheritance, gene interactions and fitness costs. PLos one, 7(2), e31582.

Jood, S., Kapoor, A., and Singh, R. (1996). Chemical composition of cereal grains as affected by storage and insect infestation. Tropical agriculture, 73(1996), 161-164.

Kaur, R., Subbarayalu, M., Jagadeesan, R., Daglish, G., Nayak, M., Naik, H. R., Ramasamy, S., Subramanian, C., Ebert, P. R., and Schlipalius, D. (2015). Phosphine resistance in India is characterised by a dihydrolipoamide dehydrogenase variant that is otherwise unobserved in eukaryotes. Heredity, 115(3), 188.

Koçak, E., Schlipalius, D., Kaur, R., Tuck, A., Ebert, P., Collins, P., and Yilmaz, A. (2015). Determining phosphine resistance in rust red flour beetle, 
Tribolium castaneum (Herbst.) (Coleoptera: Tenebrionidae) populations from Turkey. Turkish Journal of Entomology, 39(2).

Lorini, I., Collins, P. J., Daglish, G. J., Nayak, M. K., and Pavic, H. (2007). Detection and characterisation of strong resistance to phosphine in Brazilian Rhyzopertha dominica (F.)(Coleoptera: Bostrychidae). Pest management science, 63(4), 358-364.

Nath, N. S., Bhattacharya, I., Tuck, A. G., Schlipalius, D. I., and Ebert, P. R. (2011). Mechanisms of phosphine toxicity. Journal of toxicology, 1-9.

Nayak MK, Holloway JC, Emery RN, Pavic H, Bartlet J, Collins PJ (2013). Strong resistance to phosphine in the rusty grain beetle, Cryptolestes ferrugineus (Stephens) (Coleoptera: Laemophloeidae): its characterisation, a rapid assay for diagnosis and its distribution in Australia. Pest Manage Sci 69: 48-53.

Opit, G., Phillips, T. W., Aikins, M. J., and Hasan, M. (2012). Phosphine resistance in Tribolium castaneum and Rhyzopertha dominica from stored wheat in Oklahoma. Journal of Economic Entomology, 105(4), 11071114.

Rafter, M. A., McCulloch, G. A., Daglish, G. J., and Walter, G. H. (2017). Progression of phosphine resistance in susceptible Tribolium castaneum (Herbst) populations under different immigration regimes and selection pressures. Evolutionary applications.
Rajendran, S. (1998). Phosphine resistance in stored grain insect pests in India. Paper presented at the Proceedings of the 7th International Working Conference on Stored-Product Protection.

Schlipalius, D. I., Cheng, Q., Reilly, P. E., Collins, P. J., and Ebert, P. R. (2002). Genetic linkage analysis of the lesser grain borer Rhyzopertha dominica identifies two loci that confer high-level resistance to the fumigant phosphine. Genetics, 161(2), 773-782.

Schlipalius, D. I., Tuck, A.G., Pavic, H., Daglish,G.J., Nayak,M.K., Ebert, P. R., (2018). A high-throughput system used to determine frequency and distribution of phosphine resistance across large geographical regions. Pest Management Science, 75: 1091-1098.

Schlipalius, D. I., Valmas, N., Tuck, A. G., Jagadeesan, R., Ma, L., Kaur, R., Goldinger, A., Anderson, C., Kuang, J., Zuryn, S., and Zuryn, S. (2012). A core metabolic enzyme mediates resistance to phosphine gas. Science, 338(6108), 807810.

Schlipalius, D., Chen, W., Collins, P., Nguyen, T., Reilly, P., and Ebert, P. (2008). Gene interactions constrain the course of evolution of phosphine resistance in the lesser grain borer, Rhyzopertha dominica. Heredity, 100(5), 506.

White, G.G. and T.A. Lambkin. 1990. Baseline response to phosphine and resistance status of stored grain pests in Queensland, Australia. Journal of Stored Product Research, 83(3): 1738 - 1744.

\section{How to cite this article:}

Taraka, C. and Mohankumar, S. 2019. Frequency and Distribution of rph2 Gene in Tribolium castaneum Collected from Grain Supply Chain of Coimbatore, Kangeyam and Theni. Int.J.Curr.Microbiol.App.Sci. 8(11): 1839-1848. doi: https://doi.org/10.20546/ijcmas.2019.811.216 